HELMINTHOLOGIA, 58, 4: 372 - 384, 2021

\title{
New records of trematode and acanthocephalan species in frogs in Erzurum Province, Turkey
}

\author{
Y. TEPE ${ }^{1, *}$, Y. YILAN ${ }^{1}$ \\ ${ }^{1}$ Department of Biology, Science Faculty, Ataturk University, Erzurum, Turkey, \\ ORCID: 0000-0002-4589-9860 (Tepe), 0000-0002-6011-7708 (Yilan), " E-mail: ytepe@atauni.edu.tr
}

Article info

Received September 17, 2021

Accepted October 27, 2021

\section{Summary}

A total of 32 frogs of two species (Rana macrocnemis, Pelophylax ridibundus) that were dissected in some lectures in Ataturk University Science Faculty Biology Department were investigated parasitologically even after the lectures between 2008 and 2014. 9 digenean species (Cephalogonimus retusus [Cephalogonimidae]; Diplodiscus subclavatus [Paramphistomotidae]; Gorgodera cygnoides, Gorgoderina vitelliloba [Gorgoderidae]; Haplometra cylindracea, Haematoloechus variegatus, Opisthioglyphe ranae, Skrjabinoeces similis and Skrjabinoeces breviansa [Plagiorchiidae]), 3 acanthocephalan species (Acanthocephalus ranae, Centrorhynchus sp., Pomphorhynchus laevis) were found. All the parasites are the first record for Erzurum province, Cephalogonimus retusus and Skrjabinoeces similis are the first records of the parasite fauna of Turkey.

Keywords: Anura; Helminths; Erzurum; Turkey

\section{Introduction}

The herpetofauna of Turkey consists of 157 species. 14 of those are newts and 14 are frogs (Baran et al., 2012). As a component of the ecosystem frogs can harbour several parasites. There are numerous studies on parasites of amphibians in Turkey as well as all over the world. In the light of the literature, it is figured out that parasites of 24 amphibian species of 29 different provinces of Turkey were investigated but frogs from Erzurum have not been studied for now (Fig. 1).

The study aims to evaluate the dissected frogs used as lecture materials and contribute to the parasite fauna of Turkey.

\section{Material and Method}

Between 2008 and 2014, a total of 32 frogs from Erzurum province of 2 species that were etherized and dissected in the Vertebrate
Laboratory and the Zoology Laboratory lectures were investigated parasitologically even after.

The visceral organs of the frogs, that were died with high-dose ether and dissected, were put into the petri dishes filled with saline water. After the macro investigation, parasites were separated from tissues with needles, forceps and tiny brushes. The trematodes and acanthocephalans were relaxed with an Alcohol-Formalin-Acetic Acid mixture and mounted in Canada balsam according to Pritchard and Kruse (1982). The description of the parasites was executed under the light of the literature (Skrjabin, 1947, 1949, 1950, 1952, 1953, 1962, 1974; Prudhoe \& Bray, 1982) and description of the frogs was done according to Budak and Göçmen (2008).

\section{Ethical Approval and/or Informed Consent}

This study was approved by Ataturk University Local Ethics Council Of Animal Experiments Erzurum/TURKEY (36643897-118).

\footnotetext{
$\bar{*}$ - corresponding author
} 


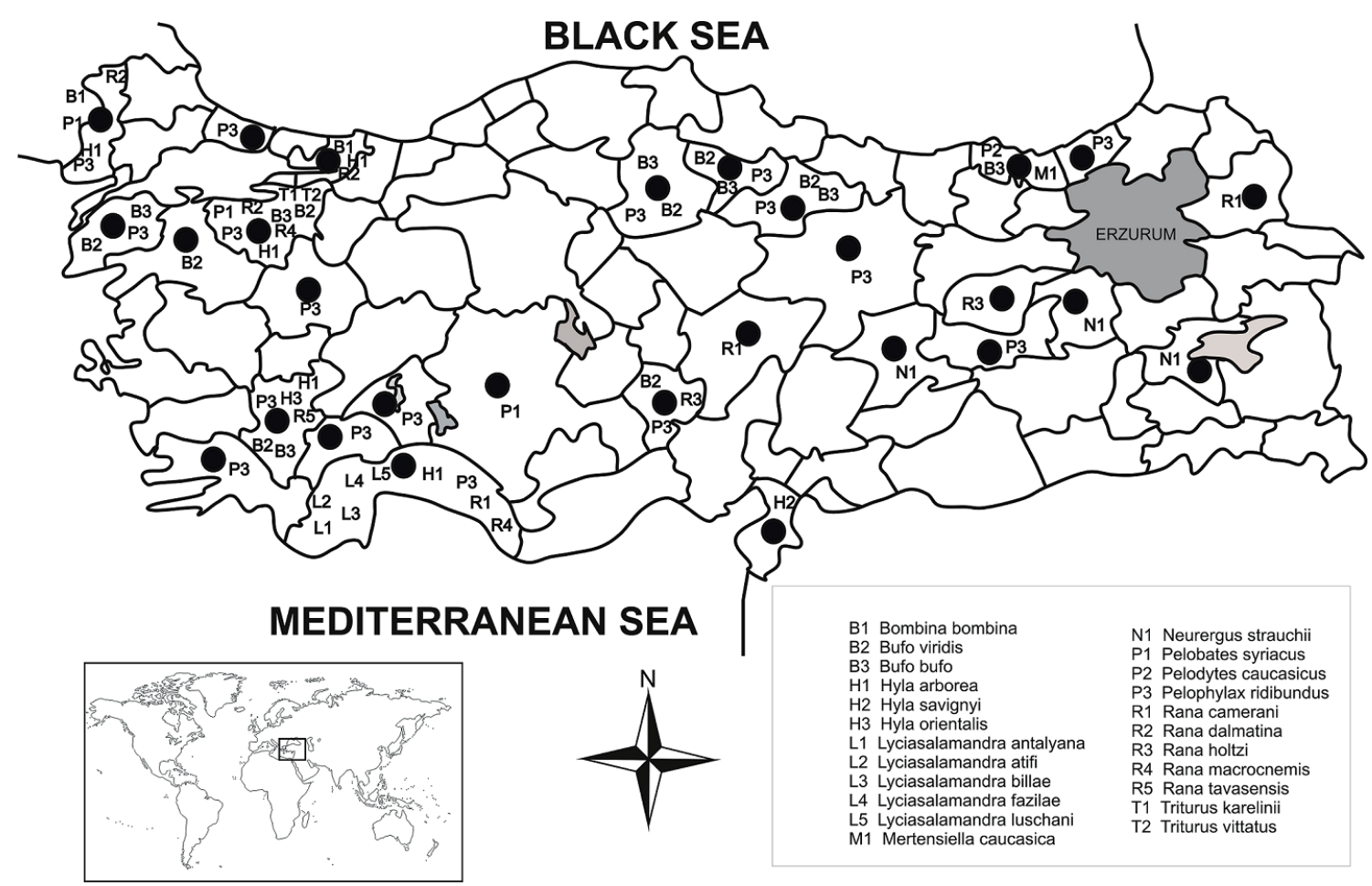

Fig. 1. Provinces of Turkey where studies on frog parasites have been made.

Results and Discussion

A total of 32 frogs of 2 species were investigated and 149 parasites of 12 species were found. While one of Rana macrocnemis (17 \%) didn't harbour any parasite species, 4 of Pelophylax ridi- bundus ( $15 \%$ ) were found parasite free. Of the investigated frogs, $27(84 \%)$ harboured one or more helminth parasites. One of the $P$. ridibundus was parasitized with 5 different helminth species. Acanthocephalus ranae is the most prevalent parasite (34\%). 3 different helminth species were come across in Rana macrocnemis

Table 1. Statistical data of parasites of $R$. macrocnemis and $P$. ridibundus

\begin{tabular}{|c|c|c|c|c|c|c|c|}
\hline HOST & & PARASITE & IFN & TPN & PREV & MA & Ml \\
\hline \multirow{4}{*}{$\begin{array}{l}\text { Rana macrocnemis } \\
(\mathrm{n}=6)\end{array}$} & \multirow[t]{3}{*}{$\mathrm{D}$} & Dolichosaccus rastellus & 2 & 34 & 33 & 17.0 & 5.7 \\
\hline & & Haplometra cylindracea & 2 & 10 & 33 & 5.0 & 1.7 \\
\hline & & Gorgodera cygnoides & 1 & 2 & 17 & 2.0 & 0.3 \\
\hline & A & Acanthocephalus ranae & 1 & 4 & 17 & 4.0 & 0.7 \\
\hline \multirow{11}{*}{$\begin{array}{l}\text { Pelophylax ridibundus } \\
\text { ( } \mathrm{n}=26)\end{array}$} & \multirow[t]{8}{*}{$\mathrm{D}$} & Cephalogonimus retusus & 3 & 4 & 12 & 1.3 & 0.2 \\
\hline & & Diplodiscus subclavatus & 5 & 24 & 19 & 4.8 & 0.9 \\
\hline & & Gorgodera cygnoides & 5 & 11 & 19 & 2.2 & 0.4 \\
\hline & & Gorgoderina vitelliloba & 1 & 1 & 4 & 1.0 & 0.01 \\
\hline & & Haematoloechus variegatus & 1 & 2 & 4 & 2.0 & 0.1 \\
\hline & & Opisthioglypha ranae & 5 & 31 & 19 & 6.2 & 1.2 \\
\hline & & Skrjabinoeces similis & 1 & 2 & 4 & 2.0 & 0.1 \\
\hline & & Skrjabinoeces breviansa & 1 & 1 & 4 & 1.0 & 0.1 \\
\hline & \multirow[t]{3}{*}{$A$} & Acanthocephalus ranae & 10 & 17 & 38 & 1.7 & 0.7 \\
\hline & & Centrorhynchus sp. & 1 & 3 & 4 & 3.0 & 0.1 \\
\hline & & Pomphorhynchus sp. & 3 & 4 & 12 & 1.3 & 0.2 \\
\hline
\end{tabular}

(IFN: Infected Frog Number; TPN: Total Parasite Number; PREV: Infection rate; MA: Mean Abundance; MI: Mean Intensity; D: Digenea; A: Acanthocephala; $\mathbf{N}$ : Nematoda) 
while 11 parasite species were found in Pelophylax ridibundus. (Table 1), (Figs. 2, 3).

\section{Platyhelminthes}

\section{Digenea}

\section{Cephalogonimidae}

Cephalogonimus retusus (Dujardin, 1845)

Synonym: Cephalogonimus europaeus

Host: Pelophylax ridibundus

Site of infection: intestine

Geographic range: Bulgaria, Czechoslovakia and Germany

Remarks: Cephalogonimideans are parasites of chelonian reptiles and amphibians, the intermediate host is Helisoma sp. (Gastropoda) (Prudhoe \& Bray, 1982).

The body is $4 \mathrm{~mm}$ in length and covered with spines. Testicles are just behind the ventral sucker and anterior half of the body. The ovary is pretesticular, and the uterus reaches the posterior end. The vitelline glands are located between the pharynx and the level of the posterior margin of the rear testis (Fig. 2e).

Cephalogonimus retusus was recorded before in Pelophylax esculentus (Lühe, 1909b; Dawes, 1946; Walton, 1949; Vojtkova \& Vojtek, 1975; Erhan \& Gherasim, 2015); Pelophylax ridibundus (Walton, 1949; Vojtkova \& Vojtek, 1975; Bray et al., 2005); Rana temporaria (Vojtkova \& Vojtek, 1975); Natrix tessellata (Buchvarov et al., 2000); Malpolon monspessulanus and Coluber jugularis (Kirin, 1994).

In the study, morphological and anatomical features of $C$. retusus was convenient with those mentioned by Skrjabin (1950). C. retusus was recorded only in the intestine of $P$. ridibundus and the infection rate was $12 \%$. It is found in Turkey for the first time.

\section{Gorgoderidae}

Gorgodera cygnoides (Zeder, 1800)

Synonym: Distomum cygnoides

Host: Pelophylax ridibundus, Rana macrocnemis

Site of infection: Bladder

Geographic range: Czechoslovakia, Germany, Poland, Russia, Tatarstan, Turkey

Remarks: Gorgoderids are small and non-spinous trematodes and found in fishes, amphibians and reptiles but Gorgodera and Gorgoderina live in amphibians (Prudhoe \& Bray, 1982).

The body is $6.5 \mathrm{~mm}$ long. The ventral sucker is distinctly larger than the oral sucker. Testes are divided into nine follicles arranged in two longitudinal rows. The ovary is pretesticular. Vitelline glands are located at the anterior region of the ovary and form two symmetrically disposed oval masses (Fig. 2f).

Gorgodera cygnoides was found before in Bombina bombina and Bombina variegata (Vojtkova \& Vojtek, 1975); Bufo igneus (Gurlt, 1845); Pelodytes caucasicus (Yildirimhan et al., 2009); Pelophylax esculentus (Lühe, 1909b; Dawes, 1946; Walton, 1949; (Vojtkova
\& Vojtek, 1975; Gurlt, 1845; Andre, 1913; Yildirimhan et al., 2005; Düşen \& Öz, 2006; Chikhlyaev et al., 2009a; Düşen et al., 2010; Popiołek et al., 2011); Pelophylax lessonae (Vojtkova \& Vojtek, 1975; Popiołek et al., 2011); Pelophylax ridibundus (Vojtkova \& Vojtek, 1975; Popiołek et al., 2011; (Koyun et al., 2015); Rana arvalis (Vojtkova \& Vojtek, 1975); Rana camerani (Yildirimhan et al., 2006a); Rana dalmatina (Yildirimhan et al., 2016); Rana temporaria (Lühe, 1909b; Dawes, 1946; Vojtkova \& Vojtek, 1975; Andre, 1913; Linstow, 1878),.

In the study, anatomical and morphological features of G. cygnoides was the same as those given by Skrjabin (1952). G. cygnoides was recorded in the urinary bladder of both $R$. macrocnemis $(\mathrm{n}=11,17 \%)$ and $P$. ridibundus $(\mathrm{n}=2,19 \%)$. G. cygnoides has been found in some provinces of Turkey before but in Erzurum, it is the first record.

\section{Gorgoderina vitelliloba (Olsson, 1876)}

Synonym: Distomum vitellilobum, Distomum cygnoides juv. Gorgoderina simplex, Gorgodera vitelliloba

Host: Pelophylax ridibundus

Site of infection: Urinary bladder

Geographic range: Czechoslovakia, Germany, Iran, Russia, Tatarstan, Turkey

Remarks: Gorgoderina vitelliloba is a parasite of the urinary bladder of amphibians (Prudhoe \& Bray, 1982).

The body is almost $2.5 \mathrm{~mm}$ and non-spinous. The ventral sucker is larger than the oral one. Testes are large and located at the posterior half of the body. The ovary is lobed and pretesticular. Vitelline glands are situated in the anterior region of the ovary (Fig. 2c).

Gorgoderina vitelliloba is detected formerly in Bombina bombina and Bombina variegata (Vojtkova \& Vojtek, 1975); Pelophylax esculentus (Lühe, 1909b; Dawes, 1946; Walton, 1949; Vojtkova \& Vojtek, 1975; Chikhlyaev et al., 2009a; Chikhlyaev et al., 2009b; Rezvantseva et al., 2010); Pelophylax bedriagae (Demir et al., 2015); Pelophylax ridibundus (Walton, 1949; Yildirimhan et al., 2005; Düşen \& Öz, 2006; Düşen et al., 2010; Koyun et al., 2015; Sağlam \& Arıkan, 2006; Saeed et al., 2007; Rezvantseva, 2008; Rezvantseva, 2009; Düşen \& Oğuz, 2010; Karakaş, 2015); Rana arvalis (Vojtkova \& Vojtek, 1975); Rana camerani (Yildirimhan et al., 2006a); Rana macrocnemis (Yildirimhan et al., 1997a); Rana temporaria (Linstow, 1878; Lühe, 1909b; Dawes, 1946; Vojtkova \& Vojtek, 1975).

Gorgoderina vitelliloba were found in Pelophylax bedriagae, Pelophylax esculentus, Pelophylax ridibundus, Rana camerani and Rana macrocnemis from some provinces of Turkey. According to Skrjabin (1953) length of G.vitelliloba is $6-8 \mathrm{~mm}$ but in the study, the specimen recorded in the urinary bladder of $P$. ridibundus was $2.5 \mathrm{~mm}$ in length. Other morphological and anatomical features are the same as those given in the literature mentioned before. The infection rate is $4 \%$. It is found in frogs of Erzurum province for the first time. 

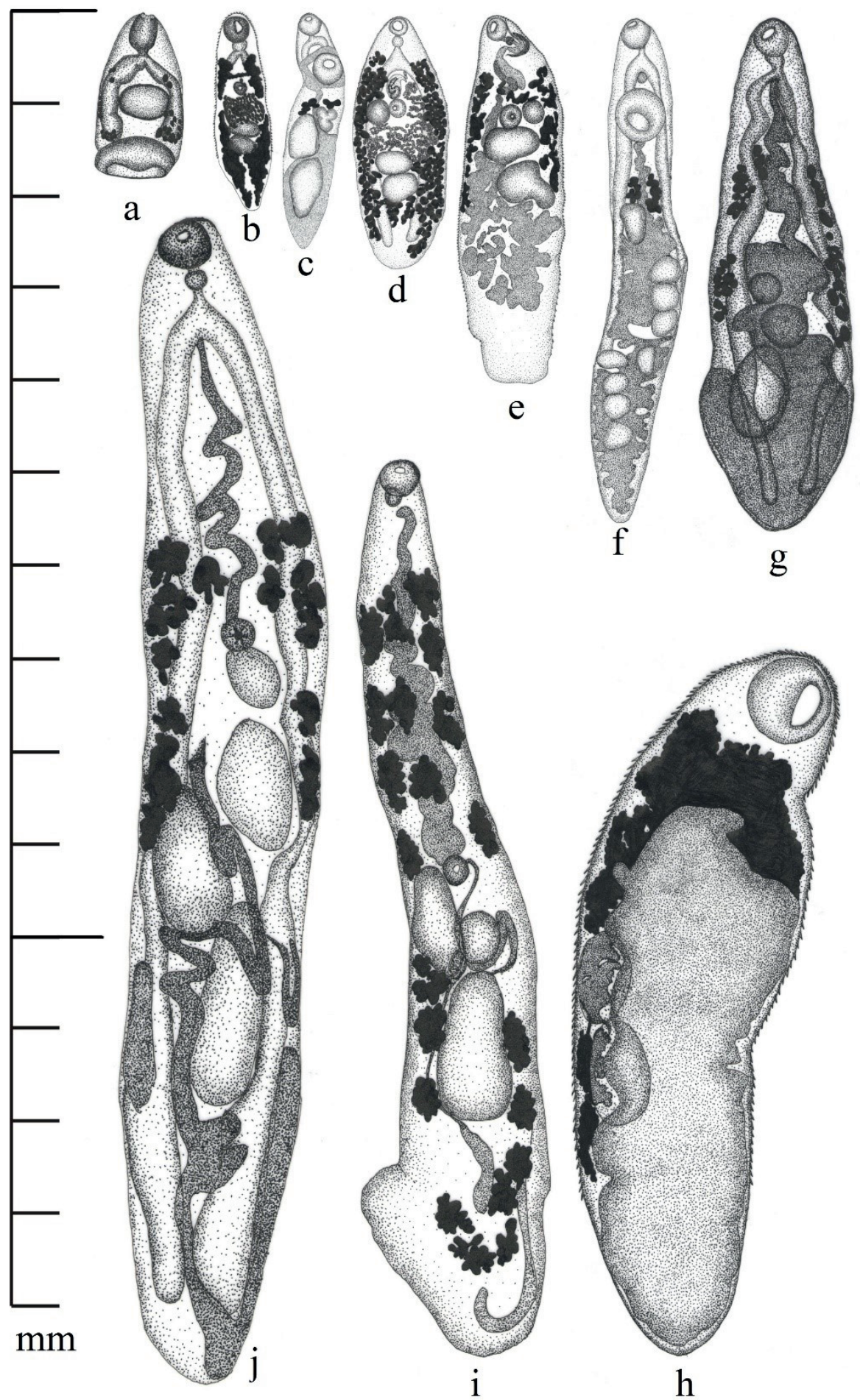

Fig. 2. Digenean parasites of frog from Erzurum (a: Diplodiscus subclavatus, b: Dolichosaccus rastellus, c: Gorgoderina vitelliloba, d: Opisthioglyphe ranae, e: Cephalogonimus retusus, f: Gorgodera cygnoides, g: Skrjabinoeces breviansa, h: Haplometra cylindracea, i: Haematoloechus variegatus, j: Skrjabinoeces similis). 

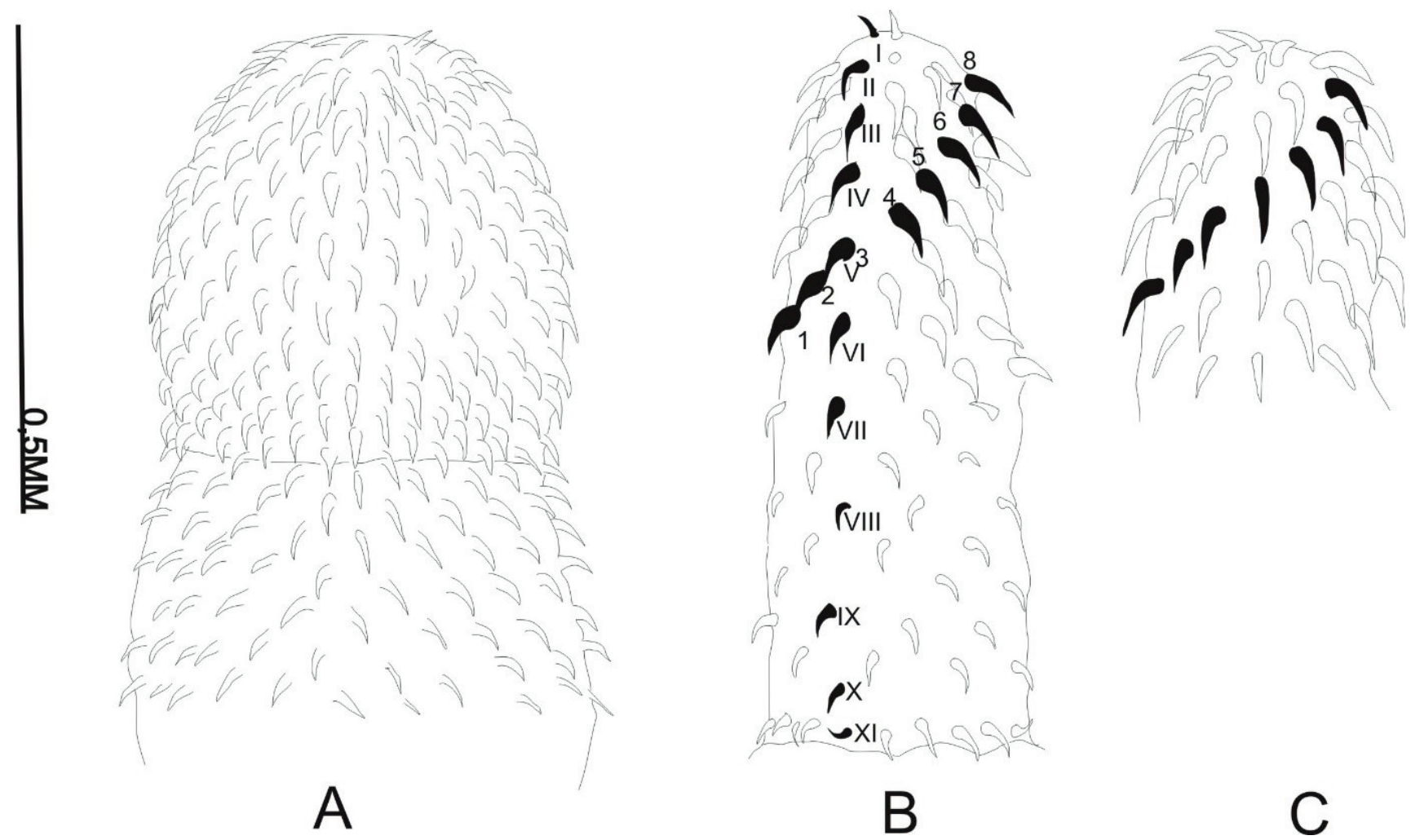

Fig. 3. Structure of proboscis of Acanthocephalans (A: Centrorhynchus sp., B: Pomphorhynchus laevis, C: Acanthocephalus ranae).

\section{Paramphistomidae}

Diplodiscus subclavatus (Goeze, 1782)

Synonym: Planaria subclavatus, Amphistomum subclavatum

Host: Pelophylax ridibundus

Site of infection: Large intestine, rectum

Geographic range: Africa, Austria, Bulgaria, Czechoslovakia, England, Iran, Italy, Moldova, Russia, Serbia, Swiss, Tatarstan, Turkey.

Remarks: Diplodiscus subclavatus (Goeze, 1782) lives in the rectum and intestine of frogs (Prudhoe \& Bray, 1982).

Nonspinous body is $2 \mathrm{~mm}$ long. The ventral sucker is very large and located at the posterior end of the body. The single testis is situated at the median line and anterior of the ovary. Vitelline follicles extend along the caeca (Fig. 2a).

It was previously encountered in Bombina bombina (Lühe, 1909b; Vojtkova \& Vojtek, 1975; Gurlt, 1845; Diesing, 1835; Diesing, 1851); Bombina variegata (Vojtkova \& Vojtek, 1975); Bufo sp. (Skrjabin, 1916); Bufo bufo (Dawes, 1946; Vojtkova \& Vojtek, 1975); Bufo cinereus, (Diesing, 1835); Bufo viridis, (Lühe, 1909b; Vojtkova \& Vojtek, 1975; Linstow, 1878; Diesing, 1851); Bufo vulgaris (Lühe, 1909b; Gurlt, 1845; Linstow, 1878); Dicroglossus occipitalis (Maeder, 1973); Dendrohyas viridis, (Diesing, 1851); Esox lucius (Öztürk et al., 2000); Hyla arborea, (Lühe, 1909b; Vojtkova \& Vojtek, 1975; Gurlt, 1845; Linstow, 1878; Diesing, 1835); Hyla savignyi (Yildirimhan et al., 2012); Leptodactylus sibilatrix, (Gurlt,
1845; Linstow, 1878; Diesing, 1835; Diesing, 1851); Molge alestris and Molge vulgaris (Lühe, 1909b); Natrix natrix and Natrix tessellata (Buchvarov et al., 2000); Pelobates fuscus (Ruchin et al., 2008; Ruchin et al., 2009; Vojtkova \& Vojtek, 1975); Pelophylax esculentus, (Lühe, 1909b; Dawes, 1946; Vojtkova \& Vojtek, 1975; Gurlt, 1845; Andre, 1913; Popiołek et al., 2011; Diesing, 1835; Diesing, 1851; Stossich, 1890; Bjelić-Čabrilo et al., 2009; Chikhlyaev et al., 2009b); Pelophylax lessonae (Vojtkova \& Vojtek, 1975; Popiołek et al., 2011); Pelophylax bedriagae (Demir et al., 2015); Pelophylax ridibundus (Vojtkova \& Vojtek, 1975; Erhan \& Gherasim, 2015; Yildirimhan et al., 2005; Düşen \& Öz, 2006; Chikhlyaev et al., 2009a; Düşen et al., 2010; Popiołek et al., 2011; Koyun et al., 2015; Rezvantseva et al., 2010; Rezvantseva, 2008; Rezvantseva, 2009; Oğuz et al., 1994; Mashaii et al., 2000; Romanova et al., 2010; Indiryakova et al., 2012); Phryne vulgaris (Diesing, 1851); Rana arvalis (Vojtkova \& Vojtek, 1975; Ruchin et al., 2009); Rana dalmatina (Vojtkova \& Vojtek, 1975; Düşen et al., 2009); Rana temporaria (Lühe, 1909b; Dawes, 1946; Vojtkova \& Vojtek, 1975; Gurlt, 1845; Linstow, 1878; Diesing, 1835; (Diesing, 1851); Salamandra maculate (Gurlt, 1845); Triton alpestris (Linstow, 1878); Triturus vulgaris (Dawes, 1946).

Diplodiscus subclavatus was recorded in some frogs i.e. Hyla savignyi, Pelophylax bedriagae, Pelophylax ridibundus, Rana dalmatina, and in a fish Esox lucius from Turkey. Morphological and anatomical features are convenient with that given by Skrjabin 
(1949). In the study, D. subclavatus was found in the rectum of $P$. ridibundus and the infection rate is $19 \%$. It is the first record for Erzurum province.

\section{Plagiorchiidae}

Dolichosaccus rastellus (Olsson, 1876) Travassos, 1930

Synonym: Distomum rastellus, Distomum endolobum, Opisthioglyphe rastellus, Opisthioglyphe histrix, Lecithopyge rastellus rastellus, Lecithopyge rastellus subulatum, Lecithopyge rastellus cylindriforme

Host: Rana macrocnemis

Site of infection: intestine

Geographic range: Czechoslovakia, England, Germany, Greece, Poland, Russia, Turkey

Remarks: Adults of the $D$. rastellus is found in the intestine of the amphibians and reptiles and larvae develops in the limnid snails (Prudhoe \& Bray, 1982).

Body covered with dense spines and almost $2 \mathrm{~mm}$ long. Oral sucker is larger than the ventral sucker. Testes are oblique, the ovary is median and located at anterior of testes. Vitelline follicles are extending from the pharyngeal region to the posterior end of the body. The uterus lays between the anterior testis and ventral sucker (Fig. 2b).

Dolichosaccus rastellus was encountered before in an ephemeropteran Cloeon dipterum (Lühe, 1909b); and in Bombina bombina (Vojtkova \& Vojtek, 1975); Bombina variegata (Vojtkova \& Vojtek, 1975; Sattmann, 1990); Pelophylax esculentus (Dawes, 1946; Vojtkova \& Vojtek, 1975); Rana arvalis (Vojtkova \& Vojtek, 1975; Ruchin et al., 2009); Rana camerani (Yildirimhan et al., 2006a; Düşen, 2007); Rana temporaria (Lühe, 1909b; Dawes, 1946; Vojtkova \& Vojtek, 1975; Gassmann, 1972); Triturus alpestris (Sattmann, 1990).

The length of the $D$. rastelus is smaller than given by Skrjabin (1974), the other features are convenient with the literature. In the study, Dolichosaccus rastellus is recorded in the intestine of $R$. macrocnemis from Erzurum for the first time.

\section{Opisthioglyphe ranae (Frôlich, 1791)}

Synonym: Fasciola ranae, Distoma endolobum, Distomum retusum, Monostomum histrix, Opisthioglyphe endoloba, Opisthioglyphe histrix

Host: Pelophylax ridibundus

Site of infection: intestine

Geographic range: Bulgaria, Czechoslovakia, England, Germany, Greece, Iraq, Iran, Hungary, Poland, Russia, Serbia, Turkey,

Remarks: Larvae of Opisthioglyphe ranae occur in Limnea stagnalis and $L$. palustris, adults harbour in the intestine of anurans (Dawes, 1946).

The body is covered with spines and $3 \mathrm{~mm}$ long. Testes are median and disposed one behind other at about hinder a third of the body. The ovary is submedian and adjacent to the ventral sucker. Vitelline glands are located mainly lateral of caeca, extending between intestinal bifurcation to the posterior end of the body (Fig. 2d). Bombina bombina and Bombina variegata (Vojtkova \& Vojtek, 1975); Bufo bufo (Dawes, 1946; Vojtkova \& Vojtek, 1975); Bufo calamita (Lühe, 1909b; Dawes, 1946; Vojtkova \& Vojtek, 1975); Bufo viridis, (Lühe, 1909b; Vojtkova \& Vojtek, 1975; Chikhlyaev, 2014); Bufo vulgaris (Lühe, 1909b); Hyla arborea (Vojtkova \& Vojtek, 1975), Molge cristata (Lühe, 1909b); Pelobates fuscus (Ruchin et al., 2008; Ruchin et al., 2009); Pelophylax esculentus (Lühe, 1909b; Dawes, 1946; Vojtkova \& Vojtek, 1975; Erhan \& Gherasim, 2015; Andre, 1913; Chikhlyaev et al., 2009a; Popiołek et al., 2011; Chikhlyaev et al., 2009b; Rezvantseva et al., 2010; Bjelić-Čabrilo et al., 2009; Gassmann, 1972); Pelophylax lessonae (Vojtkova \& Vojtek, 1975; Popiołek et al., 2011); Pelophylax ridibundus (Vojtkova \& Vojtek, 1975; Yildirimhan et al., 2005; Düşen \& Öz, 2006; Popiołek et al., 2011; Koyun et al., 2015; Saeed et al., 2007; Rezvantseva, 2008; Rezvantseva, 2009; Düşen \& Oğuz, 2010; Karakaş, 2015; Mashaii et al., 2000; Romanova et al., 2010; Indiryakova et al., 2012; Sattmann, 1990; Kirin \& Buchvarov, 1999); Rana arvalis (Vojtkova \& Vojtek, 1975; Ruchin et al., 2009); Rana dalmatina (Vojtkova \& Vojtek, 1975), Rana temporaria (Lühe, 1909b; Dawes, 1946; Vojtkova \& Vojtek, 1975; Andre, 1913); Triturus palustris (Dawes, 1946); Natrix natrix (Edelényi, 1963).

The general features of Opisthioglyphe ranae are convenient with that given by Skrjabin (1974). The dimension of specimens of the study is larger than that given in the literature. 0 . ranae was encountered only in the intestine of Pelophylax ridibundus from Turkey but was newly recorded in Erzurum province in this study.

\section{Haplometra cylindracea (Zeder, 1800)}

Synonym: Distoma cylindraceum, Distoma (Dicrocoelium) cylindraceum,

Host: Rana macrocnemis

Site of infection: Lungs

Geographic range: Czechoslovakia, England, Iraq, Iran, Russia, Tatarstan, Turkey

Remarks: Haplometra cylindracea is a common parasite of the lung of frogs throughout Europe and Northern Asia, larvae develop in the snails (Prudhoe \& Bray, 1982).

The spinous body is almost $8 \mathrm{~mm}$ in length. Testes are large and located at the posterior third of the body. The uterus occupies most of the area between the intestinal caeca and extends to the posterior end of the body. Vitelline follicles are located between intestinal bifurcation and hinder the margin of the posterior testis (Fig. 2h).

H. cylindracea was found before in Bombina bombina an Bombina variegata (Vojtkova \& Vojtek, 1975); Bufo bufo (Dawes, 1946), (Vojtkova \& Vojtek, 1975); Bufo viridis (Vojtkova \& Vojtek, 1975); Pelophylax esculentus (Dawes, 1946), (Vojtkova \& Vojtek, 1975; Chikhlyaev et al., 2009a; Rezvantseva et al., 2010); Pelophylax ridibundus (Vojtkova \& Vojtek, 1975; Saeed et al., 2007; Rezvantseva, 2008; Rezvantseva, 2009); Rana arvalis (Vojtkova \& Vojtek, 1975; Ruchin et al., 2009); Rana camerani (Yildirimhan 
et al., 2006a; Düşen, 2007); Rana dalmatina (Vojtkova \& Vojtek, 1975; Yildirimhan et al., 2016); Rana lessonae (Vojtkova \& Vojtek, 1975); Rana macrocnemis (Düşen, 2007); Rana macrocnemis pseudodalmatina (Mashaii et al., 2008); Rana tavasensis (Düşen, 2012); Rana temporaria (Lühe, 1909b; Dawes, 1946; Vojtkova \& Vojtek, 1975; Gurlt, 1845; Andre, 1913; Linstow, 1878; Gassmann, 1972).

All the characteristic features are the same as those given by Skrjabin (1958). Haplometra cylindracea is the first record for Rana macrocnemis from Erzurum.

Haematoloechus variegatus (Rudolphi, 1819)

Synonym: Distoma variegatus, Distoma variegatum, Pneumonoeces variegatus

Host: Pelophylax ridibundus

Site of infection: Lungs

Geographic range: Czechoslovakia, England, Germany, Poland, Russia, Serbia, Tatarstan, Turkey

Remarks: Adults of Haematoloechus variegatus are found in the lungs of the various terrestrial anurans and larvae can be found in freshwater snails of all zoogeographical regions (Prudhoe \& Bray, 1982).

The body is non-spinous and almost $1 \mathrm{~cm}$. Ventral sucker is smaller than oral sucker and situated in front of the mid-body. Testes are ovoid and situated side by side in the third quarter of the body. The ovary is ovoid and situated in front of the testes. Vitelline glands extend as ten to twelve rosette-like groups of six to seven follicles on each side from the level of the oesophagus almost to the posterior extremity. The uterus is irregularly folded in front of the gonads and extends between the testes and the posterior extremity (Fig. 2i). It was found in Bombina bombina and Bombina variegata (Vojtkova \& Vojtek, 1975); Bufo bufo (Dawes, 1946); Bufo viridis (Vojtkova \& Vojtek, 1975; Chikhlyaev, 2014); Pelobates fuscus (Ruchin et al., 2008); Pelophylax esculentus (Lühe, 1909b; Dawes, 1946; Walton, 1949; Vojtkova \& Vojtek, 1975; Erhan \& Gherasim, 2015; Gurlt, 1845; Andre, 1913; Chikhlyaev et al., 2009a; Popiołek et al., 2011; Chikhlyaev et al., 2009b; Rezvantseva et al., 2010; Bjelić-Čabrilo et al., 2009; Gassmann, 1972); Pelophylax lessonae (Vojtkova \& Vojtek, 1975; Popiołek et al., 2011); Pelophylax ridibundus (Walton, 1949; Vojtkova \& Vojtek, 1975; Popiołek et al., 2011; Sağlam \& Arıkan, 2006; Rezvantseva, 2008; Rezvantseva, 2009; Indiryakova et al., 2012); Rana arvalis (Vojtkova \& Vojtek, 1975; Ruchin et al., 2009); Rana temporaria (Dawes, 1946; Vojtkova \& Vojtek, 1975).

The main differences between the Skrjabinoeces and Haematoloechus genera are the number and location of the vitelline glands. The vitelline glands of genus Skrjabinoeces is located at the midbody, but the glands of genus Haematoloechus lays between laterally intestinal bifurcation and hind-body (Skrjabin, 1962). All the taxonomic characters of the species are convenient with that given by Skrjabin (1962). Haematoloechus variegatus is found in many countries of Asia and Europe including Turkey but it has not been recorded before in Erzurum province so far.

Skrjabinoeces breviansa (Loss, 1899) Sudarikov, 1950

Synonym: Haematoloechus breviansa

Host: Pelophylax ridibundus

Site of infection: Lungs

Geographic range: Iran, Russia, Turkey, Ukraine

Remarks: Skrjabinoeces sp. lives in the lungs of frogs and toads (Prudhoe \& Bray, 1982).

The body is $5.5 \mathrm{~mm}$ and covered with spines. Testes are located at the posterior third of the body. Ascending and descending limbs of the uterus occupy between the caeca. Large follicles of vitellarine glands extend laterally between the ventral sucker and fore-testis (Fig. 2g).

Skrjabinoeces breviansa was recorded before in Pelophylax esculentus (Kovalenko, 2007); Pelophylax bedriagae (Demir et al., 2015); Pelophylax ridibundus (Yildirimhan et al., 2005; Düşen \& Öz, 2006; Koyun et al., 2015; Düşen \& Oğuz, 2010; Karakaş, 2015; Mashaii et al., 2000; Romanova et al., 2010; Indiryakova et al., 2012; Kovalenko, 2007).

Morphological and anatomical characteristics of Skrjabinoeces breviansa are the same as those given by Skrjabin (1962). S. breviansa has been recorded in $P$. ridibundus from Erzurum for the first time.

\section{Skrjabinoeces similis (Loss, 1899)}

Synonym: Haematoloechus similis, Haematoloechus similigenus, Distoma simile, Distoma variegatum, Pneumonoeces similis, Pneumonoeces similigenus.

Host: Pelophylax ridibundus

Site of infection: Lungs

Geographic range: Bulgaria, Czechoslovakia, England, Germany, Iraq, Iran, Russia, Swiss, Tatarstan

Remarks: Skrjabinoeces similis is found in the lung of the frog and toads, larvae develop in the planorbid snails (Prudhoe \& Bray, 1982).

The body is covered with spines and $13 \mathrm{~mm}$ long. Ventral sucker is smaller than oral sucker and located at mid-region of body. Testes are ovoid, and the ovary is located near the ventral sucker. Vitelline glands are disposed of large follicles, ranging laterally from the anterior of the ventral sucker to the anterior testis (Fig. 2j).

Skrjabinoeces similis was encountered in Bombina bombina (Vojtkova \& Vojtek, 1975); Pelophylax esculentus (Lühe, 1909b; Dawes, 1946; Vojtkova \& Vojtek, 1975; Mashaii et al., 2000); Pelophylax ridibundus (Vojtkova \& Vojtek, 1975; Andre, 1913; Chikhlyaev et al., 2009a; Chikhlyaev et al., 2009b; Rezvantseva et al., 2010; Saeed et al., 2007; Rezvantseva, 2008; Rezvantseva, 2009; Romanova et al., 2010; Indiryakova et al., 2012; Mashaii et al., 2008; Buchvarov \& Irikov, 1997); Rana arvalis (Ruchin et al., 2009); Rana temporaria (Dawes, 1946).

Morphometric characteristics of Skrjabinoeces similis are the same as those given by Skrjabin (1962). The species has not been 
recorded in Turkey. It is the first record for Erzurum province and parasite fauna of Turkey.

\section{Acanthocephala}

\section{Echinorhynchidae}

Acanthocephalus ranae (Schrank, 1788) Lühe, 1911

Synonym: Echinorhynchus ranae

Host: Pelophylax ridibundus, Rana macrocnemis

Site of infection: intestine

Geographic range: Brazil, Bulgaria, Germany, Greece, Hungary, Poland, Romania, Russia, Serbia, Swiss, Turkey, USA

Remarks: Acanthocephalus ranae lives in the intestine of some frogs and newts generally in Europe and the larva is parasitic in Asellus aquaticus (Lühe, 1911).

The trunk is cylindrical. Short and conical proboscis has $5-6$ hooks at $12-16$ rows. The proboscis sac is the same length as the proboscis. Testes are oval and located at the mid-region of the body (Fig. 3c).

A. ranae was encountered before in Anguis fragilis (Shimalov et al., 2000); Asellus aquaticus (Lühe, 1911); Bombina bombina (Lühe, 1911); Bufo bufo (Gassmann, 1972; Yildirimhan \& Karadeniz, 2007; Düşen, 2011; Heckmann et al., 2011); Bufo viridis (Karakaş, 2015; Lühe, 1911; Yildirimhan, 1999); Bufo vulgaris (Lühe, 1911); Coronella austriaca (Edelényi, 1963); Diemyctylus viridescens (Vancleave, 1922); Hyla arborea (Heckmann et al., 2011), Hyla orientalis (Düşen \& Yaka, 2014; Yakar et al., 2016); Molge cristata (Lühe, 1911); Molge vulgaris (Lühe, 1911); Natrix natrix (Edelényi, 1963); Pelophylax esculentus (Andre, 1913; Popiołek et al., 2011; Bjelić-Čabrilo et al., 2009; Gassmann, 1972; Lühe, 1911); Pelophylax lessonae (Popiołek et al., 2011); Pelophylax bedriagae (Demir et al., 2015); Pelophylax ridibundus (Yildirimhan et al., 2005; Düşen \& Öz, 2006; Popiołek et al., 2011; Koyun et al., 2015; Sağlam \& Arıkan, 2006; Düşen \& Oğuz, 2010; Karakaş, 2015; Oğuz et al., 1994; Sattmann, 1990; Buchvarov \& Irikov, 1997; Heckmann et al., 2011; lacob, 2021); Rana camerani (Yildirimhan et al., 2006a); Rana dalmatina (Düşen et al., 2009; Yildirimhan et al., 2016), (Heckmann et al., 2011); Rana macrocnemis (Yildirimhan et al., 1997a), (Düşen, 2007), (Heckmann et al., 2011); Rana tavasensis (Heckmann et al., 2011; Düşen, 2012); Rana temporaria (Andre, 1913; Gassmann, 1972; Lühe, 1911); Rhinella icterica (Pilati et al., 2013).

A. ranae, which was found formerly in urodeles and anurans from the countries of Europe, Asia and America have been found in some provinces of Turkey, but it is the first record for Erzurum province.

\section{Centrorhynchidae}

\section{Centrorhynchus sp. Lühe 1911}

Synonym: Chentrorhynchus; Chentrosoma; Gordiorhynchus; Paradoxites; Travassosina.

Host: Pelophylax ridibundus
Site of infection: intestine

Geographic range: Bulgaria, Porto Rico, Turkey

Remarks: Adults of the acanthocephalan genus Centrorhynchus

(Polymorphida: Centrorhynchidae) occur primarily in birds of prey (Richardson \& Nickol 1995).

The trunk is non-spinous and slender. The proboscis is divided into two regions and the anterior swollen region has 8 hooks per $26-28$ rows, the posterior region has $3-4$ hooks per $26-28$ rows. Testes are in the anterior portion of the trunk (Fig. 3a).

Centrorhynchus sp. was recorded before in Eupsophus sp. (Torres \& Puga, 1996); Herpestes javanicus auropunctatus (Cable \& Quick, 1954); Pelophylax ridibundus (Yildirimhan et al., 2005).

While it was found only one individual in $P$. ridibundus from Istanbul formerly by Yildirimhan et al. (2005), Centrorhynchus sp. is the first record for Erzurum province.

\section{Pomphorhynchidae}

Pomphorhynchus laevis (Zoega in Müller, 1776) Van Cleave, 1924

Synonym: Echinorhynchus laevis; Echinorhynchus tereticollis; Pomphorhynchus tereticollis; Echinorynchus proteus; Pomphorhynchus proteus; Pomphorhynchus intermedius.

Host: Pelophylax ridibundus

Site of infection: intestine

Geographic range: Iraq, Turkey

Remarks: Species of Pomphorhynchus are largely parasites of freshwater fishes (Amin et al., 2003).

The trunk is non-spinous and spindle-shaped.

We recorded at $2010 P$. spindletruncatus from some freshwater fish of Erzurum province and marsh frogs of Isparta province (Heckmann et al., 2010). The difference of $P$. laevis from $P$. spindletruncatus is mainly the number of the proboscis' hooks. The proboscis of $P$. spindletrucatus is ovoid and $15-18$ longitudinal rows of $7-9$ hooks of each and proboscis of $P$. laevis cylindrical to ovoid, with $16-18$ longitudinal rows of $11-12$ hooks of each. The neck is moderate length and has a distal bulb (Fig. $3 b$ ).

$P$. laevis was recorded in freshwater fishes as Abramis brama, Abramis sapa, Acipenser ruthenus, Alburnus alburnus (Nedeva et al., 2003); Alburnus baliki (Aydoğdu et al., 2011); Anguilla anguilla (Sures, 2001); Apollina melanostoma (Kvach \& Skora, 2007; Rolbiecki, 2006; Ondrackova et al., 2005); Aspius aspius (Nedeva et al., 2003); Barbus barbus (Nedeva et al., 2003; Schludermann et al., 2003; Laimgruber et al., 2005; Brown et al., 1986; Thielen et al., 2004); Blicca bjorkna and Carassius auratus gibelio (Nedeva et al., 2003); Crenilabrus tinca (Akmirza, 2002); Cyprinus carpio (Buhurcu, 2006); Gobius niger (Zander, 2004); Gymnocephalus shraetser, Lota lota, Neogobius cephalarges, and Pelecus cultratus (Nedeva et al., 2003); Neogobius fluviatilis and Neogobius kessleri (Ondrackova et al., 2005); Neogobius iljini (Mineeva, 2013); Perca fluviatilis (Sobecka \& Słomińska, 2007), (Nedeva et al., 2003); Phoxinus phoxinus (Kralova-Hromadova et al., 2003; Dudiňák \& Šnábel, 2001); Platychthys flesus (Koie, 1999), (Chib- 
ani et al., 2001); Pomatoschistus minutus (Zander, 2004); Rutilus rutilus (Nedeva et al., 2003); Salmo gairdneri (Brown et al., 1986); Scardinius erhythrophthalmus, Silurus glanis (Nedeva et al., 2003); Squalius cephalus (Kralova-Hromadova et al., 2003; Bombarova et al., 2007; Dudińák \& Šnábel, 2001; Brown et al., 1986; Dezfuli et al., 1999; Tieri et al., 2006; Galli et al., 2001; Dudiňák \& Šnábel, 2001); Stizostedion lucioperca (Nedeva et al., 2003); Symphodus tinca (Çinar, 2014); Tinca tinca (Yildiz, 2003; Yildiz \& Çavuşoğlu, 2003); Vimba vimba (Nedeva et al., 2003); in marsh frogs (Pelophylax ridibundus) (Düşen \& Öz, 2013; Düşen \& Oğuz, 2008; Düşen \& Oğuz, 2010) and in an otter (Lutra lutra) (Dimitrova et al., 2008).

Pomphorhynchus laevis is found in the frog from Erzurum for the first time.

As a result, a total of 149 individuals of parasites of 12 species were found in frogs. As the parasite fauna of Pelophylax ridibundus and Rana macrocnemis of Erzurum province have not been studied before, our study is very important for contribution to fauna. While all the parasites are the first records for Erzurum, Skrjabinoeces similis and Cephalogonimus retusus are the first records for parasite fauna of Turkey.

\section{Conflict of Interest}

The authors state no conflict of interest.

\section{References}

AkmiRZA, A. (2002): Acanthocephala and Cestoda Parasites Fishes Caught Near Gökçeada. Turkiye Parazitol Derg, 26(1) (In Turkish) Amin, O.M., Abdallah, S.M.A., Mhaisen, F.T. (2003): Description of Pomphorhynchus spindletruncatus $\mathrm{n}$. sp. (Acanthocephala: Pomphorhynchidae) from freshwater fishes in northern Iraq, with the erection of a new pomphorhynchid genus, Pyriproboscis n. g., and keys to genera of the Pomphorhynchidae and the species of Pomphorhynchus Monticelli, 1905. Syst Parasitol, 54: 229 - 235

ANDRE, E. (1913): Recherches parasitologiques sur les amphibiens de la suisse II [Parasitological research on amphibians in Switzerland II]. Rev Suisse Zool, 21: 79 - 200 (In French)

Aydoğdu, A., Emre, Y., Emre, N., KüçüK, F. (2011): Two new host records for Pomphorhynchus laevis (Müller, 1776) (Acanthocephala) recorded from Antalya, Turkey: Small bleak (Alburnus baliki Bogutskaya, Küçük \& Ünlü, 2000) and Antalya barb (Capoeta antalyensis Battalgil, 1944). Turk Zool Derg, 35(6): 897 - 900. DOI:10.3906/zoo-0909-32

Baran, I., Ilgaz, Ç., Avcl, A., Kumlutaş, Y., Olgun, K. (2012). Türkiye amfibi ve sürüngenleri, 3 edn. [Amphibians and reptiles of Turkey, 3rd ed] Ankara: TÜBITAK. 203 pp. (In Turkish)

Buelić-Č́abrilo, O., Popović, E., Paunović, A. (2009): Helminthofauna of Pelophylax kl. esculentus (Linne, 1758) from petrovaradinski rit marsh (Serbia). Helminthologia, 46(2): 107 - 111. DOI: 10.2478/ s11687-009-0021-z
Bombarova, M., Marec, F., Nguyen, P., Spakulova, M. (2007): Divergent location of ribosomal genes in chromosomes of fish thorny-headed worms, Pomphorhynchus laevis and Pomphorhynchus tereticollis (acanthocephala). Genetica, 131(2): 141 - 149. DOI: 10.1007/s10709-006-9124-3

Bray, R.A., Webster, B.L., Bartoli, P., Littlewood, D.T.J. (2005): Relationships within the Acanthocolpidae Lühe,1906 and their place among the Digenea. Acta Parasitologica, 50(4): 281 - 291

Brown, A.F., ChubB, J.C., Veltcamp, J.C. (1986): A key to the species of Acanthocephala parasitic in British freshwater fishes. J. Fish. Biol., 28: 327 - 334

BuCHVAROV, G., IRIKOV, A. (1997): Le renseiqnement de la helmintofaune de la grande grenouille aguatigue (Rana ridibunda Pall) provenant du region du combinat de la production du cuivre, nomnie "G. Damianov" a pirdop [Information on the helmintho-fauna of the great water frog (Rana ridibunda Pall) from the region of the copper production complex, called "G. Damianov" in pirdop]. Trav. Sci. Univ. Plovdiv, Animalia, 33(6): 45 - 54 (In French)

Buchvarov, G., KIRIN, D., Kostadinova, A. (2000): Platyhelminth parasite assemblages in two species of snakes, Natrix natrix and Natrix tessellata (Reptilia: Colubridae), from Bulgaria: Seasonal variation. J. Environ. Prot. Ecol., 1(1): 124 - 131

Budak, A., Göçmen, B. (2008). Herpetology. Ege University Faculty of Science Books Series, No. 194, Ege University Press, Bornova-Izmir, 226 p. (In Turkish)

Buhurcu, H.I. (2006): Studies on the endoparasite fauna of some fish (Cyprinus carpio Linnaeus, 1758, Alburnus nasreddini Battalgil, 1944) in Lake Akşehir. Master Thesis, Afyon: Afyon Kocatepe University. (In Turkish)

CABle, R.M., Quick, L.A. (1954): Some Acanthocephala from Puerto Rico with the description of a new genus and three new species. Trans Am Microsc Soc, 73(4): 393 - 400

Chibani, M., ZIokowskay, M., KIJeWskay, A., Rokicki, J. (2001): Pomphorhynchus laevis parasite of flounder Platichthys flesus as a biological indicator of pollution in the Baltic Sea. J. Mar. Biol. Ass. U.K., 81: $165-166$

CHIKHLYAEV, I.V. (2014): On the fauna helminthes of green toad Bufo viridis Laurenti, 1768 (Anura, Amphibia) in Samara Region [Russian]. Samarskaya Luka : Problemy Regionalnoy i Globalnoy Ekologii, 23(2): 185 - 190

Chikhlyaev, I.V., Fayzulin, A.I., Zamaletdinov, R.I. (2009b): Edible frog helminths - Rana esculenta Linnaeus, 1758 (Anura, Amphibia) of the middle Volga region. Povolzhsky Ecol. J., , 3: 270 - 274 (In Russian)

Chikhlyaev, I.V., Fayzulin, A.I., Zamaletdinov, R.I., Kuzovenko, A.E. (2009a): [Trophic relationships and helminthic fauna of green frogs Rana esculenta complex (Anura, Amphibia) in urbanized areas of the Volga basin]. Pratsi Ukrainian Herpetological Association, 2: 102 - 109. (In Russian)

ÇINAR, M.E. (2014): Checklist of the Phyla Platyhelminthes, Xenacoelomorpha, Nematoda, Acanthocephala, Myxozoa, Tardigrada, Cephalorhyncha, Nemertea, Echiura, Brachiopoda, Phoronida, 
Chaetognatha, and Chordata (Tunicata, Cephalochordata, and Hemichordata) from the coasts of Turkey. Turk Zool Derg, 38: 698 - 722. DOI: 10.3906/zoo-1405-70

DAWES, B. (1946). The trematoda with special reference to british and other european forms. Cambridge Univ. Press. 644 pp.

DemiR, S., YaKar, O., YILDIRIMHAN, H.S., BIRLIK, S. (2015): Helminth parasites of the levantine frog (Pelophylax bedriagae camerano, 1882) from the western part of Turkey. Helminthologia, 52(1): 71 76. DOI 10.1515/helmin-2015-0013

Dezfuli, B.S., Capuano, S., Pironi, F., Mischiati, C. (1999): The origin and function of cement gland secretion in Pomphorhynchus laevis (Acanthocephala). Parasitology, 119: 649 - 653

Diesing, C.M. (1835): Monographie der Gattungen Amphistoma und Diplodiscus. (Tafel 22-24) [Monograph of the genera Amphistoma and Diplodiscus. (Plate 22-24)]. Annals of the Vienna Museum of Natural History, 1: 235 - 260 (In German)

DiESING, C.M. (1851). Systema helminthum. Volume 2. Vindobonae. 588 pp.

Dimitrova, Z., TZVetKov, Y., Todev, I. (2008): Occurrence of acanthocephalans in the eurasian otter Lutra lutra (L.) (Carnivora, Mustelidae) in Bulgaria, with a survey of Acanthocephalans recorded from this host species. Helminthologia, 45(1): 41 - 47. DOI: 10.2478/s11687-008-0007-2

DudIŇÁK, V., ŠNÁBEL, V. (2001): Comparative analysis of Slovak and Czech Populations of Pomphorhynchus laevis (Acanthocephala) using morphological and isoenzyme analyses. Acta Zool. Univ. Comen., 44: $41-50$

Düşen, S. (2007): Helminths of the two mountain frogs, banded frog, Rana camerani Boulenger, 1886 and Uludağ frog Rana macrocnemis Boulenger, 1885 (Anura: Ranidae), collected grom the Antalya province. Türkiye Parazitol Derg, 31(1): 84 - 88

Düşen, S. (2011): The helminth parasites of the two Bufonid toads, European common toad, Bufo bufo (Linnaeus, 1758) and european green toad, Bufo (Pseudepidalea) viridis Laurenti, 1768 (Anura: Bufonidae), collected from denizli province, inner-west Anatolia Region, Turkey. Helminthologia, 48(2): 101 - 107. DOI: 10.2478/ s11687-011-0019-1

Düşen, S. (2012): First data on the helminth fauna of a locally distributed mountain frog, "Tavas frog" Rana tavasensis Baran \& Atatür, 1986 (Anura: Ranidae), from the inner-west Anatolian region of Turkey. Turk. J. Zool., 36(4): 496 - 502. DOI: 10.3906/ Z00-0909-15

Düşen, S., OĞUz, M. (2008): Occurence of Pomphorhynchus laevis (Acanthocephala) in the marsh frog (Rana ridibunda pallas, 1771), from Turkey. Helminthologia, 45(3): 154 - 156. DOI: 10.2478/ s11687-008-0031-2

Düşen, S., OĞUz, M.C. (2010): Metazoan endoparasites of three species of anurans collected from the Middle Black Sea region of Turkey. Helminthologia, 47(4): 226 - 232. DOI: 10.2478/s11687010-0035-6

Düşen, S., OĞuz, M.C., Barton, D.P., Aral, A., Şulekoğlu, S., Tepe, Y. (2010): Metazoan parasitological research on three species of anurans collected from Çanakkale province northwestern Turkey. North West J Zool, 6(1): 25 - 35

DüşEN, S., Öz, M. (2006): Helminths of the marsh frog, Rana ridibunda pallas, 1771 (Anura : Ranidae), from Antalya province, Southwestern Turkey. Comp Parasitol, 73(1): 121 - 129. DOI: 10.1654/4162.1

Düşen, S., Öz, M. (2013): Helminth fauna of the eurasian marsh frog, Pelophylax ridibundus (Pallas, 1771) (Anura: Ranidae), collected from Denizli province, inner-west anatolia region, Turkey. Helminthologia, 50(1): 57 - 66. DOI: 10.2478/s11687-013-0108-4 Düşen, S., UĞurtaş, I.H., AydoĞdu, A., OĞuz, M.C. (2009): The helminth community of the agile frog, Rana dalmatina Bonaparte, 1839 (Anura: Ranidae) collected from northwest of Turkey. Helminthologia, 46(3): 177 - 182. DOI: 10.2478/s11687-009-0033-8

DüșEN, S., YAKA, H. (2014): Helminths of the eastern tree frog, Hyla orientalis, Bedriaga, 1890 (Anura: Hylidae), collected from Denizli province, inner-west Anatolia Region, Turkey. Helminthologia, 51(1): 37 - 45. DOI: 10.2478/s11687-014-0206-y

EDELÉNYI, B. (1963): Hazai hüllők néhány újabb belsőélősködő férge. (einige neuere innere parasitenwürmer der in ungarn lebenden reptilien) [Some new internal parasitic worms of domestic reptiles.] Az Egri Tanárképző Főiskola tudományos közleményei (1. köt.) = Acta Academiae Paedagogicae Agriensis 1: 323-342. (In Hungarian)

Erhan, D., Gherasim, E. (2015): Trematodofauna complexului Pelophylax esculenta (Amphibia, Anura) din codrii centrali ai republicii Moldova. 1. Familiile Plagiorchiidae, Cephalogonimidae [Trematodofauna of the Pelophylax esculenta complex (Amphibia, Anura) from the central forests of the Republic of Moldova. 1. The families Plagiorchiidae, Cephalogonimidae]. Studia Universitatis Moldaviae. Real and Natural Sciences Series 81(1): 148 - 159. (In Romanian)

Galli, P., Crosa, G., Mariniello, L., Ortis, M., D'amelio, S. (2001): Water quality as a determinant of the composition of fish parasite communities. Hydrobiologia, 452: $173-179$

GassmanN, M. (1972): Etudes des trematodes et acanthocephales d'amphibiens du jura [Studies of trematodes and acanthocephales of amphibians of the Jura]. Rev Suisse Zool, 79(3): 980 - 998 (In French)

GURLT, E.F. (1845): Verzeichniss der thiere, bei welchen entozoen gefunden worden sind [List of animals in which entozoa have been found]. Arch. Naturg., 1: 223 - 325. (In German)

Heckmann, R.A., Amin, O.M., Tepe, Y., Düșen, S., OĞuz, M.C. (2011): Acanthocephalus ranae (Acanthocephala: Echinorhynchidae) from amphibians in Turkey, with special reference to new morphological features revealed by sem, and histopathology Sci. Parasitol., 12(1): $23-32$

Heckmann, R.A., OĞuz, M.C., Amin, O.M., Dusen, S., Tepe, Y., Aslan, B. (2010): Host and geographical distribution of Pomphorhynchus spindletrancatus (Acanthocephala: Pomphorhynchidae) in Turkey, with enhanced description from new fish and amphibian hosts using SEM, and histopathological notes. Sci. Parasitol., 11: 
$129-139$

IACOB, O.C. (2021): Parasitism with Acanthocephalus ranae in frogs (Pelophylax ridibundus Pallas 1771), from North-East Romania. Helminthologia, 10;58(1):68 - 73. DOI: 552 10.2478/Helm2021-0008

IndiRYAKova, T.A., Romanova, E.M., IndiRYAKova, O.A. (2012): [Assessment of the ecological state of the suburban biotopes of the Sviyaga River according to the parameters of the biodiversity of the parasite fauna Rana ridibunda Pallas, 1971]. Bulletin of the Ulyanovsk State, 49-54. (In Russian)

KaRAKAŞ, M. (2015): Helminth parasites of Bufo viridis, Rana ridibunda and Hyla arborea collected from the different regions of Turkey. Manas J. Agric. Life Sci., 5(1): 1 - 6

KIIIN, D. (1994): Metaleptophallus gracillimus (Luhe, 1909) (Family Plagiorchidae, Lurhe, 1901) and Cephalogonimus retusus (Dijardin, 1845), (Family Cephalogonimidae, Nicol, 1915), new species of the helminth fauna of the Reptiles (Reptilia) in Bulgaria. Trav. Sci. Univ. Plovdiv, Animalia, 30(6): 41 - 46 (In Bulgarian)

KIRIN, D., BuchVAROV, G. (1999): Larval forms on helminthes on a homes and wilds animals, parasiting in lake frog (Rana ridibunda Pall) from region of Plovdiv. Trav. Sci. Univ. Plovdiv, Animalia, 35(6): $21-28$

KoIE, M. (1999): Metazoan parasites of flounder Platichthys flesus (L.) along a transect from the southwestern to the northeastern Baltic Sea. ICES J Mar Sci, 56: 157 - 163

KovalenKo, M.V. (2007): First Ukrainian record of the frog lung fluke Skrjabinoeces breviansa Sudarikov, 1950 (Trematoda: Plagiorchidae). J. V.N. Karazin Kharkiv Nat. Univ., Ser. "Biol.", 93 - 96 KoYun, M., BIRLIK, S., SÜmer, N., YILDIRIMHAN, H.S. (2015): Helminth fauna of eurasian marsh frog, Pelophylax Ridibundus (Pallas, 1771) (Anura: Ranidae) from Bingöl, Eastern Anatolia, Turkey. Biharean Biol, 9(2): 128 - 132

Kralova-Hromadova, I., Tietz, D.F., Shinn, A.P., Špakulova, M. (2003): Its rDNA sequences of Pomphorhynchus laevis (Zoega in Müller, 1776) and P. Lucyi Williams \& Rogers, 1984 (Acanthocephala: Palaeacanthocephala). Syst Parasitol, 56: 141 - 145. DOI: 10.1023/A:1026127219358

KVACH, Y., SkoRA, K.E. (2007): Metazoa parasites of the invasive round goby Apollonia melanostoma (Neogobius melanostomus) (Pallas) (Gobiidae: Osteichthyes) in the gulf of Gdansk, Baltic Sea, Poland: A comparison with the Black Sea. Parasitol Res, 100(4): 767 - 774. 10.1007/s00436-006-0311-z

Laimgruber, S., Schludermann, C., Konecny, R., Chovanec, A. (2005): Helminth communities of the barbel Barbus barbus from large river systems in Austria. J Helminthol, 79(2): 143 - 149. DOI: 10.1079/joh2005276

LINSTow, O. (1878): Compendium der helminthologie Hanover [Compendium of helminthology]. Hanover. 580 pp. (In German) LÜHE, M. (1909b): Parasitische plattwürmer. I: Trematodes [Parasitic Flatworms. I: Trematodes]. Die Süsswasserfauna Deutschlands, eine Exkursionsfauna, 17: 1 - 217. (In German)

LÜHE, M. (1911): Acanthocephalans. Süsswasserfauna 16. 1 - 60
MAEDER, A.M. (1973): Monogènes et trématodes parasites d'amphibiens en côte d'ivoire [Monogens and parasitic trematodes of amphibians in the Ivory Coast]. Revue Suisse Zool, 80(2): 267 322. (In German)

Mashail, N., Balouch, M., Mobedi, I. (2000): New records about helminth parasites of the marsh frog, Rana ridibunda ridibunda (Anura: Ranidae) from the north of Iran. Iran. J. Fish. Sci., 2(2): 77 - 88 MASHAII, N., BALOUCH, M., MoBeDI, I. (2008): A report about helminth parasites of some amphibians (Anura: Ranidae, bufonidae) from the north and northeast of Iran. JSUT, 33(4): 9 - 13

MineEva, O.V. (2013): Parasitofauna of the goby (Neogobius iljini Vasiljeva et Vasiljev, 1996), of the saratov reservoir. Vestn. Nižegorodskogo univ. im. N.I. Lobačevskogo, 4(1): 158 - 161

Nedeva, I., Atanassov, G., Karaivanova, E., Cakic, P., Lenghardi, M. (2003): Pomphorhynchus laevis (Miller, 1776) from the River Danube. Exp. Pathol. Parasitol., 6(13): $14-16$

OĞUz, M.C., Altunel, F.N., UĞURTAŞ, I.H. (1994): Edirne ve Bursa illeri çevresinde yakalanan ova kurbağası (Rana ridibunda Pallas, 1771)'nın parazitleri olan platyhelminth'leri ile Acanthocephalus rane (Schrank, 1788, Echinorhynchidae, Acanthocepahala) üzerinde araştırmalar [Investigations on platyhelminths and Acanthocephalus rane (Schrank, 1788, Echinorhynchidae, Acanthocepahala) which are parasites of the marsh frog (Rana ridibunda Pallas, 1771) caught around Edirne and Bursa provinces]. Turk. J. Zool., 18: 47 - 51. (In Turkish)

Ondrackova, M., Davidova, M., Pecinkova, M., Blazek, R., Gelnar, M., Valova, V., Cerny, J., JuRAJda, P. (2005): Metazoan parasites of neogobius fishes in the Slovak section of the River Danube. J. Appl. Ichthyol, 21: 345 - 349

Öztürk, M.O., Oguz, M.C., Altunel, F.N. (2000): Metazoan parasites of pike (Esox lucius L.) from Lake Uluabat, Turkey. Isr J Zool, 46: $119-130$

Pilati, C., Quadros, R.M., Branco, K.A.A., Andrade, M.A., Marques, S.M.T. (2013): Acanthocephalus ranae (Echinorhynchidae) infecting Rhinella icterica (Bufonidae) in Santa Catarina, Brazil. Cienc. Anim, 23(1): $3-8$

Popiolek, M., Rozenblut-Kościsty, B., Kot, M., Nosal, W., Ogielska, M. (2011): Endoparasitic helminths of water frog complex in Poland: Do differences exist between the parental species Pelophylax ridibundus and Pelophylax lessonae, and their natural Hybrid Pelophylax esculentus? Helminthologia, 48(2): 108 - 115. DOI: 10.2478/s11687-011-0020-8

PRITCHARD, M.H., KRUSE, G.O. (1982). The collection and preservation of animal parasites. Technical bulletin no. 1. The Harold W. Manter Laboratory, University of Nebraska Press. $141 \mathrm{pp}$.

Prudhoe, S., Bray, R.A. (1982). Platyhelminth parasites of the amphibia. British Museum (Natural History), Oxford Universiity Press. $217 \mathrm{pp}$.

ReZVANTSEVA, M.V. (2008): [Materials on the helminth fauna of the marsh frog (Rana ridibunda) in the vicinity of Tambov]. TSU Bulletin, 13(5): 330 - 332. (In Russian)

RezvantSeva, M.V. (2009): [Seasonal and long-term dynamics of 
the number of marsh frog (Rana ridibunda) helminths in the vicinity of Tambov]. TSU Bulletin, 14(2): 389 - 393. (In Russian)

RezvantseVA, M.V., LadA, G.A., Kulakov, E.J. (2010): [Age and sex characteristics of the helminth fauna of green frogs (Rana esculenta complex) in the east of the central black earth]. TSU Bulletin, 15(2): 646 - 659. (In Russian)

RICHARDSON, D.J., Nickol, B.B. (1995): The genus Centrorhynchus (Acanthocephala) in North America with description of Centrorhynchus robustus $\mathrm{n}$. $\mathrm{sp}$., redescription of Centrorhynchus conspectus, and a key to species. J Parasitol, 81(5): 767 - 772

RolBIECKI, L. (2006): Parasites of the round goby, Neogobius melanostomus (Pallas, 1811), an invasive species in the Polish fauna of the Vistula lagoon ecosystem. Oceanologia, 48(4): $545-561$

Romanova, E.M., Indiryakova, T.A., Matveeva, E.A. (2010): [Biotic relationships in parasitocenoses of Rana ridibunda]. UGSKA Bulletin, 1(11): 69 - 75. (In Russian)

Ruchin, A.B., ChIKHLYAEv, I.V., Lukyanov, S.V., Ryzhov, M.K. (2008): On helminths of common spadefoot toad - Pelobates fuscus (the eastern form) in floodlands of some rivers in middle and Lower-Volga Region. Povolzhsky Ecol. J., 1: 48 - 54

Ruchin, A.B., ChkLyaev, I.V., Lukyanov, S.V. (2009): [Study of the helminth fauna of the common garlic Pelobates fus- cus (laurenti, 1768) and the frog Rana arvalis Nilsson, 1842 (Amphibia: Anura) in their joint habitation]. Parasitology, 43(3): $240-247$

Saeed, I., Al-Barwarl, S.E., Al-HarmanI, K.I. (2007): A metazoan parasitological research of some Iraqi amphibians. Türkiye Parazitol. Derg., 31(4): 337 - 345

SaĞLAM, N., ArIKAN, H. (2006): Endohelminth fauna of the marsh frog Rana ridibunda from Lake Hazar, Turkey. Dis. Aquat. Org., 72: 253 - 260. DOI: 10.3354/dao072253

SATTMAnN, H. (1990): Endohelminths of some amphibians from northern Greece (Trematoda, Acanthocephala, Nematoda; Amphibia: Triturus, Rana, Bombina). Herpetozoa, 3(1/2): 67 - 71

Schludermann, C., Konecny, R., Laimgruber, S., Lewis, J.W., Schiemer, F., Chovanec, A., Sures, B. (2003): Fish macroparasites as indicators of heavy metal pollution in river sites in Austria. Parasitology, 126 Suppl.: S61 - 69. DOI: 10.1017/s0031182003003743

Shimalov, V.V., Shimalov, V.T., Shimalov, A.V. (2000): Helminth fauna of lizards (Reptilia, Sauria) in the southern part of Belarus. Parasitol. Res., 86: 343

SKRJABIN, K.I. (1916): Parasitic trematodes and nematodes collected by the expedition of prof. V. Dogiel and i. Sokolov in British east Africa. Science Research Expedition to British East Africa and Uganda, V. Dogiel and I. Sokolov in 1914, 4: 1 - 157

SkRJABIN, K.I. (1947): Trematody zhivotnyh i cheloveka [Trematodes of animals and man]. Volume 1. Izdatel'stvo Akademii Nauk SSSR, Moscow-Leningrad. 515 pp. (In Russian)

SkRJABIN, K.I. (1949): Trematody zhivotnyh i cheloveka [Trematodes of animals and man]. Volume 3. Izdatel'stvo Akademii Nauk SSSR, Moscow-Leningrad. 623 pp. (In Russian)

SKRJABIN, K.I. (1950): Trematody zhivotnyh i cheloveka [Trematodes of animals and man]. Volume 4. Izdatel'stvo Akademii Nauk
SSSR, Moscow-Leningrad. 495 pp. (In Russian)

SKRJABIN, K.I. (1952): Trematody zhivotnyh i cheloveka [Trematodes of animals and man]. Volume 7. Izdatel'stvo Akademii Nauk SSSR, Moscow-Leningrad. 762 pp. (In Russian)

SkRJABIN, K.I. (1953): Trematody zhivotnyh i cheloveka [Trematodes of animals and man]. Volume 8. Izdatel'stvo Akademii Nauk SSSR, Moscow-Leningrad. 618 pp. (In Russian)

SkRJABIN, K.I. (1958): Trematody zhivotnyh i cheloveka [Trematodes of animals and man]. Volume 14. Izdatel'stvo Akademii Nauk SSSR, Moscow-Leningrad. 934 pp. (In Russian)

SkRJABIN, K.I. (1962): Trematody zhivotnyh i cheloveka [Trematodes of animals and man]. Volume 20. Izdatel'stvo Akademii Nauk SSSR, Moscow-Leningrad. 563 pp. (In Russian)

SkRJABIN, K.I. (1974): Trematody zhivotnyh i cheloveka [Trematodes of animals and man]. Volume 24. Izdatel'stvo Akademii Nauk SSSR, Moscow-Leningrad. 379 pp. (In Russian)

SoвECKA, E., SŁomińSKA, M. (2007): Species richness, diversity and specificity of the parasites of bream Abramis brama (L.) and perch Perca fluviatilis $\mathrm{L}$. In the estuary of the Odra River, Poland. Helminthologia, 44(4): 188 - 192. DOI: 10.2478/s11687-007-0030-8

Stossich, M. (1890): Elminti veneti raccolti dal dott. Alessandro p. Ninni [Venetian helminths collected by Dr. Alessandro P. Ninni]. Boll. Soc. Adriatic., 12: 49 - 56. (In Italian)

SURES, B. (2001): The use of fish parasites as bioindicators of heavy metals in aquatic ecosystems: A review. Aquat Ecol, 35: $245-255$

Thielen, F., Zimmermann, S., Baska, F., Taraschewski, H., Sures, B. (2004): The intestinal parasite Pomphorhynchus laevis (Acanthocephala) from barbel as a bioindicator for metal pollution in the Danube River near Budapest, Hungary. Environ. Pollut., 129(3): 421 - 429. DOI: 10.1016/j.envpol.2003.11.011

Tieri, E., Mariniello, L., Ortis, M., Berti, M., Battistini, M.L. (2006): Endoparasites of chub (Leuciscus cephalus) in two rivers of the Abruzzo region of Italy. Vet Ital, 42(3): 271 - 279

ToRres, P., Puga, S. (1996): Occurrence of cystacanths of Centrorhynchus sp. (Acanthocephala:Centrorhynchidae) in toads tf the genus Eupsophus in Chile. Mem Inst Oswaldo Cruz, Rio De Janeiro, $91(6): 717-719$

VANCLEAVE, H.J. (1922): Acanthocephala from the Illinois river, with descriptions of species and a synopsis of the family Neoechinorhynchidae. Bull. III. Nat. Hist. Surv. Urbana, Illinois, U. S. A. (1918 - 1921), 13: 225 - 257

VoJTKOVA, L., VoJTEK, J. (1975): Die trematoden der amphibien in der tschechoslowakei. II. Die larvesta-dien (mesocercarien un metacercarien) [The trematodes of the amphibians in Czechoslovakia. II. The larval stages (Mesocercaria and metacercaria)]. Folia Fac. sci. nat. Univ. Purkyn. Brun., Biol., 16: 7 - 84. (In German) Walton, A.C. (1949): Parasites of the Ranidae (Amphibia) VII. Trans Am Microsc Soc, 68(1): $49-54$

Yakar, O., Demir, S., YILdIRIMHAN, H.S., BIRLIK, S. (2016): Gastrointestinal helminths of the oriental tree frog Hyla orientalis Bedriaga, 1890 (Amphibia: Hylidae) from Izmir province, western Turkey. 
Acta Zool Bulg, 68(1): 111 - 115

YILDIRIMHAN, H. S., UĞURTAȘ, I. H., ALtunel, F. N. (1997a): Rana macrocnemis Boulenger 1885 (uludağ kurbağası)'in asalak helminthleri üzerine bir araştırma [A study on parasitic helminths of Rana macrocnemis Boulenger 1885 (Uludağ frog)]. Turk. J. Zool., 21: 467 - 473. (In Turkish)

YILDIRIMHAN, H.S. (1999): Bufo viridis Laurenti, 1768 (Anura; Amphibia)'in parazitik helmintleri üzerine araştırmalar [Studies on parasitic helminths of Bufo viridis Laurenti, 1768 (Anura; Amphibia)]. Turk. J. Zool., 23(1): 177 - 195. (In Turkish)

YILDIRIMHAN, H.S., BURSEY, C.R., GoldBeRg, S.R. (2009): Helminth parasites of the caucasian parsley frog, Pelodytes caucasicus, from Turkey. Comp. Parasitol., 76(2): 247 - 257. DOI: 10.1654/4376.1 YILDIRIMHAN, H.S., GoldBERG, S.R., BURSEY, C.R. (2006a): Helminth parasites of the banded frog Rana camerani (Ranidae) from Turkey. Comp. Parasitol., 73(2): 222 - 236. DOI: 10.1654/4229.1

YILDIRIMHAN, H.S., KaRADENIZ, E. (2007): Helminth parasites of the common toad, Bufo bufo (Linnaeus, 1758) (Anura: Bufonidae) from northeast Turkey. Comp. Parasitol., 74(1). 176 - 178: DOI: 10.1654/4246.1

Yildirimhan, H.S., KaradenIz, E., GÜRKan, E., KoYun, M. (2005): Türkiye'nin değişik bölgelerinden toplanan ova kurbağası (Rana ridibunda Pallas, 1771; Anura)'nın metazoon parazitleri [Metazo- an parasites of marsh frog (Rana ridibunda Pallas, 1771; Anura) collected from different regions of Turkey]. Turkiye Parazitol Derg, 29(2): 135 - 139. (In Turkish)

YILDIRIMHAN, H.S., SüMER, N., BURSEY, C.R. (2016): Helminth parasites of the agile frog, Rana dalmatina Fitzinger, 1839 (Anura: Ranidae), collected from two localities in Turkey. Acta Zool Bulg, 68(3): $425-432$

YILdiRIMHAn, H.S., Sümer, N., İNCEdoĞan, S., BuRsey, C.R. (2012): Helminth parasites of the lemon-yellow tree frog, Hyla savignyi (Hylidae), from Turkey. Turk. J. Zool., 36(2): 171 - 184. DOI:10.3906/zoo-1006-9

YILDIZ, K. (2003): Kapulukaya baraj gölü'ndeki kadife balıklarında (Tinca tinca) helmint enfeksiyonları [Helminth infections in tench fish (Tinca tinca) in Kapulukaya reservoir]. Turk. J. Vet. Anim. Sci., 27: 671 - 675 (In Turkish)

YILDIZ, K., ÇAVuŞoĞLU, K. (2003): Pomphorhynchus laevis'in scanning elektron mikroskobik incelenmesi [SEM investigation of Pomphorhynchus laevis]. Turk. J. Vet. Anim. Sci., 27: 1357 - 1360 (In Turkish)

ZANDER, C.D. (2004): Four-year monitoring of parasite communities in gobiid fishes of the south-western Balticii. Infracommunity. Parasitol. Res., 93(1): 17 - 29. DOI: 10.1007/s00436-004-1087-7 